\title{
ARTESANIAS AUDIOVISUAIS E A PRODUÇÃO DE DRAMATURGIAS DOCENTESDISCENTES: NEGOCIAÇÕES MEDIADAS PELO DIGITAL EM REDE
}

\author{
AUDIOVISUAL CRAFTS AND THE PRODUCTION OF TEACHERS/STUDENT'S \\ DRAMATURGY: NEGOTIATIONS MEDIATED BY THE DIGITAL NETWORK
}

\section{ARTESANÍAS AUDIOVISUALES Y LA PRODUCICIÓN DE DRAMATURGIAS DOCENTESDISCENTES: NEGOCIACIONES MEDIADAS POR LO DIGITAL EN RED}

\author{
Leonardo Nolasco-Silva ${ }^{1}$ \\ Vittorio Lo Bianco ${ }^{2}$ \\ Lia Faria ${ }^{3}$
}

RESUMO: Nossa proposta é pensar, a partir do conceito de audiovisualidades, as possibilidades didáticas abertas pela cultura da convergência, seja nos cenários da Educação a Distância, seja nas paisagens da modalidade presencial. Para tanto, discutimos o papel da televisão de modo a problematizar as tecnologias educacionais e seus usos por professores e estudantes. Discutimos o nosso contato diário com a televisão comercial - no aparelho tradicional ou na palma da nossa mão - e rememoramos iniciativas que elegeram a TV como meio de praticar e dar acesso à educação formal - mais especificamente falamos da gênese e da lógica do Telecurso 2 o Grau, pensando em como aquela modalidade de ensino ainda ressoa entre as práticas atuais de EAD. Perguntamos o que ainda temos a aprender com essa lógica de produção de imagens e que espaços de invenção podemos explorar a partir dela, ampliando o repertório sobre as tecnologias educacionais na formação de professores.

Palavras-chave: Audiovisualidades; Cultura da Convergência; Educação a Distância.

RESUMEN: Nuestra propuesta es pensar, a partir del concepto de audiovisualidades, las posibilidades didácticas abiertas por la cultura de la convergencia, sea en los escenarios de la Educación a Distancia, sea en los paisajes de la modalidad presencial. Para ello, discutimos el papel de la televisión para problematizar las tecnologías educativas y sus usos por

\footnotetext{
Submetido em: 21/09/2017 - Aceito em: 30/09/2017 - Publicado em: 31/10/2017

${ }^{1}$ Pós-Doutor em Educação pela Universidade do Estado do Rio de Janeiro; Professor Adjunto da Faculdade de Educação da UERJ; Vice-líder do grupo de pesquisa Educação e República.

${ }^{2}$ Doutorando em Educação - ProPEd-UERJ; Analista em EAD da Fundação CECIERJ.

${ }^{3}$ Pós-Doutora em Educação pela Universidade de Lisboa e em Ciência Política pelo IUPERJ; Professora de graduação e pós-graduação da Faculdade de Educação da UERJ.
} 
profesores y estudiantes. Discutimos nuestro contacto diario con la televisión comercial - en el aparato tradicional o en la palma de nuestra mano - y rememoramos iniciativas que eligieron la televisión como medio de practicar y dar acceso a la educación formal - más específicamente hablamos de la génesis y de la lógica del Telecurso 2o Grado, pensando en cómo esa modalidad de enseñanza todavía resuena entre las prácticas actuales de EAD. Hemos preguntado lo que todavía tenemos que aprender con esta lógica de producción de imágenes y qué espacios de invención podemos explorar a partir de ella, ampliando el repertorio sobre las tecnologías educativas en la formación de profesores.

Palabras clave: Audiovisualidades; Cultura de la Convergencia; Educación a distancia.

ABSTRACT: Our proposal is to think, from the concept of audiovisualities, the didactic possibilities opened by the culture of convergence, whether in the scenarios of Distance Education or in the landscapes of the face-to-face modality. To do so, we discuss the role of television in order to problematize educational technologies and their uses by teachers and students. We discuss our daily contact with commercial television - in the traditional apparatus or in the palm of our hand - and we recall initiatives that have chosen TV as a means of practicing and giving access to formal education - more specifically we speak of the genesis and logic of Telecurso $2 \circ$ Degree, thinking about how that modality of teaching still resonates between the current practices of ODL. We ask what we still have to learn from this logic of image production and what spaces of invention we can explore from it, expanding the repertoire on educational technologies in teacher training.

Keywords: Audiovisuals; Culture of Convergence; Distance Education.

Este é um texto que fala sobre imagens em movimento. Ou melhor, é um texto que procura entender que movimentos são produzidos por imagens postas ao consumo na televisão - movimentos que são atos de aprendizagem, são modos de apropriação ou meios de inculcação de ideias e valores. Movimentos que são disparadores de debates, que nunca são apenas consumo, pois no ato de consumir atualizamos virtualidades, como indica Certeau (1994) ao falar da imprevisibilidade dos usos empreendidos pelos praticantes culturais.

Presente em quase todos os lares, a televisão é uma janela de informação e entretenimento, espaçotempo ${ }^{4}$ não formal de educação. A possibilidade de educar, de aprenderensinar pela tela, não está apenas nas transmissões televisivas que consumimos em

\footnotetext{
${ }^{4}$ Optamos, nas pesquisas nos/dos/com os cotidianos, por marcar em nossas grafias o entendimento de que seria mais adequado romper com algumas dicotomias que, no bojo da Modernidade, expressam modelos supostamente antagônicos. Na contramão desse movimento, escrevemos ensinaraprender, tempoespaço, práticasteorias etc.
} 


\section{Revista Docência e Cibercultura}

casa, mas remete a sistematizações elaboradas que pensaram a linguagem da TV como ferramenta pedagógica para a formação de quadros. Tanto no passado como nos dias que correm, a relação entre aparelhos de televisão e formação escolar é estreita e frutífera, ainda que vista por muitos como perigosa e indesejável. Se a televisão é inevitável, uma vez que constitui nossas práticas de ler o mundo, precisamos ir fundo no que ela tem a nos dizer - ou no que temos a falar a partir dela. Somos o país da telenovela e boa parte do que elaboramos sobre os eventos da vida passa pela ficção discutida nas reuniões de família, na rua, nos bares e, obviamente, nas escolas. Do telejornal ao jogo de bola, tudo na televisão ressoa em nosso cotidiano. Torna-se, então, necessário, subir o pano e enxergar o que existe para além da tela. Por outro lado, na era da cultura da convergência (JENKIS, apud PRIMO, 2013) é preciso reconhecer que a televisão não caminha sozinha, tendo na multiplicação de telas um processo complexo que precisamos compreender.

A proposta deste artigo é, pois, debater o nosso contato diário com a televisão comercial - seja no aparelho tradicional ou na palma da nossa mão - e com aquelas iniciativas que elegeram a TV como meio de praticar e dar acesso à educação formal - mais especificamente falamos da gênese e da lógica do Telecurso $2^{\circ} \mathrm{Grau}$, pensando em como aquela modalidade de ensino ainda ressoa entre as práticas atuais de EAD e, ousamos dizer, indagando o que ainda temos a aprender com aquela lógica de produção de imagens que, longe de ser gratuita ou espontânea, segue uma agenda político-estético-cultural de conquista da atenção do espectador e de veiculação de uma mensagem pensada para alcançar determinado público em certo tempo histórico.

Deste modo, entendemos que a nossa formação não se restringe aos espaçostemposformais de escolarização, sendo o conhecimento produzido em redes cotidianas de significações e subjetivações (ALVES, 2015). Dentre os muitos cenários nos quais aprendemosensinamos, a televisão - e suas múltiplas formas de consumo atuais merece destaque pela abrangência de sua atuação no Brasil, sendo, muito provavelmente, a tecnologia mais presente nos lares brasileiros. No exercício da profissão docente, inclusive, é preciso reconhecer a presença constante dessa tecnologia que, não raramente, aparece como disparadora de temas na sala de aula, seja porque os estudantes repercutem algo que assistiram, seja porque o próprio professor fez reverberar o que foi visto. $E$, não podemos 
esquecer, que era pelo equipamento de TV que o cinema entrava na sala de aula, acoplado ao videocassete ou, mais recentemente, ao aparelho de DVD. Tal entrada hoje em dia se dá pelo computador conectado ao Datashow.

Muito mais do que se pensa, essas professoras, em especial no espaço/tempo do cotidiano urbano sabem porque usam (e não só consomem) televisão e computador, além de geladeira, telefone, liquidificador, que escolheram e compraram, com seu pouco dinheiro, pois entendem que estes objetos (mesmo antes de serem meios) são importantes para seus/suas filhos/as e para si mesmas. Neste processo, com estes/as companheiros/as de curiosidade e aprendizagem, vão "redescobrindo" a lógica que sempre usaram no cotidiano, mas não sabiam, e que indica que o conhecimento é tecido em rede, sem caminhos obrigatórios e sem hierarquias, com uns ensinando aos outros conhecimentos que mudam permanentemente. (ALVES, 2000, pp. 33-34).

Dito de outra forma, a televisão não precisa entrar na escola como tecnologia a ser pedagogizada, mas como experiência estética vivida nos cotidianos e que transborda para espaçostempos outros, não se limitando à casa. Trazemos a programação televisiva em nossas memórias afetivas e é possível que tenhamos construído boa parte da nossa visão de mundo a partir dela. Isso não significa que, ao reconhecermos sua função formadora, estamos dizendo que mantemos com ela uma relação passiva de recepção acrítica. Também somos nós, os espectadores, que colocamos a programação televisa em movimento - seja repercutindo notícias e formas de entretenimento, seja zapeando ${ }^{5}$ e estimulando as emissoras a criar estratégias de fidelização da audiência (MARCONDES FILHO, 1994). Ainda que exista atualmente entre tantas outras possibilidades de entretenimento, a televisão mantém a sua força e é uma espécie de elo entre os nossos hábitos de consumo tradicionais e as novidades do mercado, como as redes sociais online e os dispositivos de streaming.

A televisão começa a expandir-se a partir dos anos 50 e vai rapidamente conquistando o público e ocupando um lugar importante no lazer das pessoas até que se torna, no final do século [XX], o meio de transmissão de imagens absoluto em toda a cultura. Domina todas as outras formas de transmissão de imagens assim como todos os demais media, produzidos em grande escala, como é o caso do jornal, do rádio, do cinema, da literatura.MARCONDES FILHO, 1994, p. 16).6

\footnotetext{
${ }^{5}$ Para Marcondes Filho (1994) o advento do controle remoto facilitou a prática do zaping, isto é, produziu no espectador o hábito de navegar entre os canais. Com isso, a audiência das emissoras de TV ficou menos estável, exigindo das empresas de comunicação uma maior atenção para criar conteúdos que despertem interesse no público, destituindo-o do desejo de zapear para as concorrentes.

${ }^{6}$ É bem possível que a centralidade da televisão seja hoje algo a se contestar diante do avanço das tecnologias digitais conectadas em rede.
} 


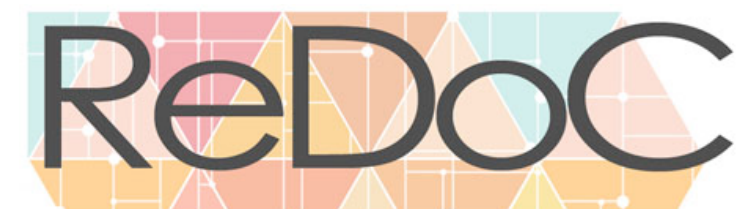

A TELEVISÃO COMO MÁQUINA PREGUIÇOSA

\section{Revista Docência e Cibercultura}

Umberto Eco (1994), ao falar da literatura, atribuía ao leitor a tarefa de fazer funcionar a "máquina preguiçosa" da escrita. Para o autor, todo texto repousa nas páginas não lidas e é preciso que o leitor o coloque em movimento, criando sentidos para aquilo que o autor escreveu. Nesta direção, por mais que ao escrever tentemos desenhar mapas para que o leitor caminhe de acordo com as nossas intenções, caberá somente a ele - ao leitor traçar o seu próprio caminho, acionando toda a rede de conhecimentos e vivências de suas tramas pessoais, aquela bagagem que nos auxilia a ler o mundo.

A obra literária seria, pois, uma "obra aberta" e convidaria o leitor a entrar em suas páginas como quem entra em um bosque - paisagem que, de repente, se bifurca, exigindo do caminhante a escolha de um caminho ou de outro. Um livro não produziria, então, um destino irremediável. Ainda que as histórias escritas conduzam nossos olhos a um ponto final, a um local de chegada, cada um de nós, ao ler um livro, caminha com bagagem própria, faz "passeios inferenciais", para a leitura, retorna um tempo depois, junta o vivido com o que foi lido, faz sínteses, associa ideias, reconhece alguém nas páginas, se identifica, cria juízos e depois, se retorna ao livro, já é outro leitor, tem marcas próprias, jamais apreensíveis pelo autor original ou por qualquer outro leitor que tenha se lançado ao desafio de adentrar no mesmo livro. Será possível usar o mesmo raciocínio para pensar a relação que temos com a televisão? Acreditamos que sim.

A programação da TV não produz nada que não possa ser refeito pelo trabalho de atualização do espectador. Basta observarmos uma conversa informal sobre alguma cena da novela das nove $e^{8}$, transmitida na noite anterior, para que verifiquemos a multiplicidade de entendimentos diante da história narrada. O mesmo acontece nas discussões sobre as notícias do telejornal ou sobre as atrações dos programas de auditório. Mais do que diversidade de opiniões, tais comportamentos revelam uma variedade de apropriações que, em tese, resultam de bac enquanto tecnologias educacionais kgrounds diversos. Por mais que soe controverso, a televisão, ao inculcar algumas ideias, padronizando determinados

\footnotetext{
${ }^{7}$ Referência ao conceito de Umberto Eco (1994). Para o autor, o texto literário é uma máquina preguiçosa que precisa ser atualizada pelo leitor. Partimos do princípio que a televisão também possui essa demanda.

${ }^{8}$ Chamamos de novela das nove a produção dramatúrgica veiculada no horário nobre da Rede Globo de Televisão, por volta das 21:15. Trata-se, historicamente, do programa de maior audiência no país. 
conteúdos, abre espaço para a discordância, para a crítica, para outros usos (CERTEAU, 1994) daquilo que ela pensa formatar. Por isso, enquanto alguns preferem denunciar o caráter nocivo da televisão, argumentamos que é imperativo pensar a TV como disparadora de debates em sala de aula, identificando-a como recurso educativo que, independente da nossa vontade ou intervenção, participará da formação de nossos estudantes.

O que não podemos desconsiderar ao elegermos a programação televisiva como disparadora de situações de ensinoaprendizagem é o fato de nem sempre pensarmos na TV como algo a que devemos reagir. Em outras palavras, nossa relação doméstica com a televisão é mais da ordem da distração do que do debate. Cabe-nos, assim, perguntar: até que ponto somos convocados a refletir sobre um programa de televisão? Quais são os espaços de problematização desta programação onde, pedagogicamente, poderíamos repensar as maneiras como enxergamos o mundo? A velocidade dos afazeres diários nem sempre nos permite mobilizar tudo o que consumimos na TV e, talvez, seja essa uma lacuna a ser preenchida pela escola - e pelos cursos de formação de professores.

O que dissemos até aqui, embora importante, não apresenta grandes novidades. A relevância da televisão como propositora de uma agenda de temas debatidos na sociedade já foi objeto dos estudos de Marcondes Filho (1994) e Bourdieu (1987), por exemplo. A pertinência de se considerar o consumo da televisão na formação de professoras também já foi o foco das pesquisas de Nilda Alves (2000). O que desejamos acrescentar ao debate é a emergência de outras práticas de consumo da TV - um consumo que é também da ordem da produção, do remix, da bricolagem de imagens e das práticas transmídia. Em paralelo, ao mostrarmos tais mudanças que são significativas nos últimos tempos, tentaremos construir o argumento de que resta algo da forma antiga de produzir conteúdos para a televisão em nossa condução didática na EAD. Falamos basicamente de uma construção discursiva que aposta em uma linearidade na interação entre emissor e receptor, ignorando a polissemia comunicativa das redes sociais online e demais autorias ciberculturais.

\section{A TV EM REDE}

Como dissemos, assistimos nos últimos anos novas maneiras de consumir as produções televisivas. A possibilidade de ampliação das telas retirou do aparelho de TV o protagonismo da transmissão de imagens, oportunizando o acesso por outros meios - 


\section{Revista Docência e Cibercultura}

computadores, tabletes, smartphones etc. Os dispositivos móveis permitem que o ritual de assistir televisão se diversifique, não sendo mais necessário estar em casa, diante da TV, na hora do seu programa favorito.

Pensando nisso, as próprias emissoras de televisão, reconhecendo a emergência de um novo público, mais conectado em rede e disposto a fazer ele próprio a sua programação, têm criado serviços ondemand para ofertar seus produtos. Tornou-se, assim, habitual a imersão em maratonas de séries de TV, onde os espectadores assistem, de uma só vez, todos os episódios disponíveis de uma ou mais temporadas. Inspirados no modelo Netflix ${ }^{9}$, onde um cardápio de produtos audiovisuais é ofertado ao consumidor, emissoras de grande porte como a Rede Globo e a Rede Record passaram a disponibilizar sua programação na rede, não só reexibindo o que passam na TV, mas também criando produtos próprios para a Internet - ou ainda antecipando capítulos e séries que só irão entrar na programação convencional no futuro. A Globo Play - aplicativo com conteúdo audiovisual da Rede Globo - oferece atualmente todos os episódios da primeira temporada de Brasil à Bordo e de Carcereiro, séries que só estrearão na TV em 2018.

A multiplicação das telas via Internet, além de diversificar o acesso aos conteúdos, também possibilitou uma nova experiência de compartilhamento e de criação de vínculos a partir da programação televisiva. Ferramentas como as hashtags (\#), por exemplo, possibilitam encontrar no Twitter usuários conectados que estejam assistindo (e repercutindo) o mesmo programa de TV e, unidas por esta estratégia de busca e catalogação de assuntos, essas pessoas - que não se conhecem, necessariamente - poderão interagir, trocar opiniões sobre o que estão vendo e, principalmente, poderão gerar novos produtos a partir do programa original. Os passeios inferenciais que citamos a partir de Umberto Eco (1994), podem ser feitos agora em companhia de outros fruidores e a máquina preguiçosapara retomar ao mesmo autor - passa a ser atualizada com mais frequência e variações de usos (CERTEAU, 1994).

A produção de memes $^{10}$, que é uma maneira de atualizar a máquina preguiçosa da TV e/ou da Internet, tem eternizado algumas cenas de novela, não só ampliando a audiência

\footnotetext{
${ }^{9}$ Referência na oferta ondemand.

${ }^{10}$ Memes são discursos (imagens, vídeos, músicas e outras formas de expressão) que viralizam na Internet e despertam o desejo de atualização. Diferente do viral que se assenta basicamente no compartilhamento, o meme (C) Redoc \begin{tabular}{l|l|ll} 
Rio de Janeiro & v.1 & n.1 & p.67 Setembro/2017
\end{tabular} ISSN 2594-9004
} 
da trama, como também produzindo novas mensagens, novos produtos e sentidos outros que escapam de toda e qualquer tentativa de controle das emissoras ou dos seus dramaturgos. As interações síncronas - que se realizam em tempo real - podem gerar interações assíncronas dali a dois dias ou dois anos. Os rastros dos efeitos provocados pela televisão ficam hospedados na rede e, de vez em quando, retornam com força total. Novelas como Senhora do Destino e Avenida Brasil, veiculadas há anos na televisão, são assuntos recorrentes hoje em dia, convertidos em memes de sucesso.

Figura 1 - Meme inspirado na personagem Nazaré, de Senhora do destino, novela exibida pela Rede Globo entre 2004 e $2005 .^{11}$

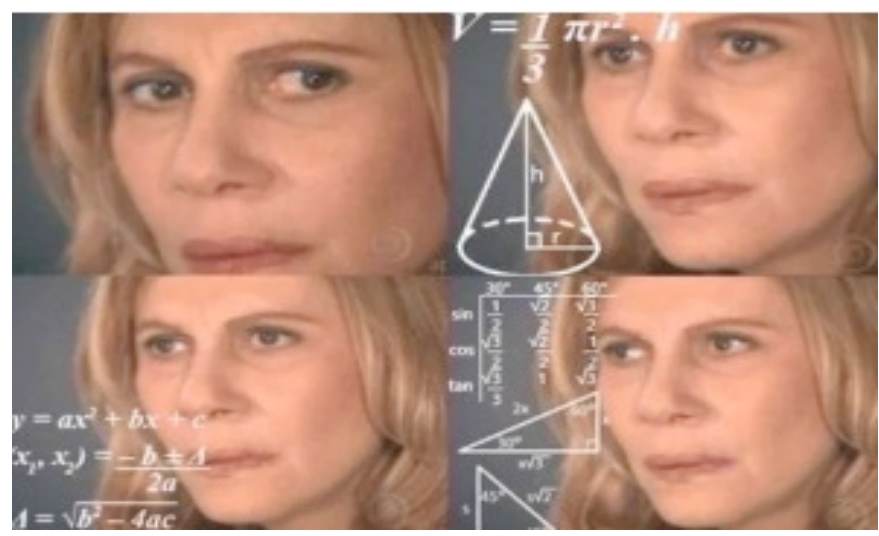

Fonte: https://goo.gl/8xpBnJ

A transformação de uma personagem de novela em meme revela a disposição dos praticantespensantes ${ }^{12}$ (OLIVEIRA, 2012) em atualizar sentidos e produzir bricolagens a partir daquilo que é consumido e tido, por muitos, como material de menor valor. Trata-se não só de um processo de apropriação textual, mas também de cocriação e de exploração de habilidades dramatúrgicas. Os memes contam uma história e são, por definição, abertos a continuidades comunicativas. É próprio dos memes ter uma origem, mas nunca um fim. $\mathrm{O}$

demanda ser modificado para se inserir em cada novo ato de compartilhar. Um meme é, pois, um discurso que se adéqua aos contextos mais variados, exigindo de quem o compartilha um trabalho de atualização e ressignificação. Originalmente, no grego, meme quer dizer imitação. Se concordarmos com BHABHA (1998) que imitação é sempre a criação do novo, podemos afirmar que produzir um meme é imitar um discurso para fazê-lo outro.

${ }^{11} \mathrm{O}$ meme tem sido usado em várias situações atuais para ilustrar o não entendimento sobre alguma coisa.

${ }^{12}$ A opção pela palavra visa demonstrar que quando falamos em praticantes não enxergamos na ação um gesto meramente mecânico, mas fruto de um saberfazer que produz conhecimentos e que fora produzido em meios a tantas outras sapiências e ignorâncias. O praticantepensante é a tentativa de religar trabalho manual e pensamento, dois elementos habitualmente dissociados na Modernidade. 


\section{Revista Docência e Cibercultura}

meme termina quando cai no esquecimento, mas há inúmeros exemplos de memes que retornam tempos depois e parece que nunca saíram de moda. Ainda que muito popular na Internet, o meme é visto como parte de uma cultura subterrânea, assim como há tempos vem sendo percebida a televisão.

Martín-Barbero (2000), todavia, considera que a nossa inserção na Modernidade com destaque para a América Latina, tem se dado muito mais pela via da produção/consumo do audiovisual do que através dos modos tradicionais de leitura, como os livros, por exemplo. Nessa observação não reside necessariamente uma crítica a esse tipo de prática, mas a percepção de que estamos nos constituindo muito especialmente a partir das imagens. Segundo Martín-Barbero (2000, pp. 83-84):

por mais escandaloso que nos soe, é um fato que as maiorias na América Latina estão se incorporando à modernidade não sob o domínio do livro, mas a partir dos discursos e das narrativas, dos saberes e das linguagens da indústria e da experiência audiovisual. [...] a cumplicidade e a interpenetração entre oralidade cultural e linguagens audiovisuais não remetem - como pretende boa parte de nossos intelectuais e nossos anacrônicos sistemas educativos - nem às ignorâncias, nem ao exotismo do analfabetismo, mas a descentramentos culturais que em nossas sociedades estão produzindo os novos regimes de sentir e de saber, que passam pela imagem catalisada pela televisão e o computador.

Por meio das imagens e, sobretudo, das imagens em movimento, sejam elas da TV, do cinema ou dos vídeos hospedados no Youtube, vamos experimentando outras formas de letramento. Vamos construindo argumentos, desenvolvendo roteiros, elaborando textualidades que pretendem dar conta da vida, entre selfies, postagens, likes e compartilhamentos. Mas fazemos tudo isso sem romper definitivamente com o que fazíamos no passado e sublinhar isso é imperativo quando pensamos em analogias possíveis entre a produção, distribuição e consumo audiovisuais e a formação docente.

\section{A EDUCAÇÃO E A CULTURA DA CONVERGÊNCIA}

A incorporação de um vasto número de tecnologias eletrônicas e digitais em nossas vidas não implica, como já dissemos, na automática substituição de saberesfazeres anteriores, tampouco significa a ruptura com certo modo de existência. Os novíssimos 
dispositivos - que mudam a cada dia seguindo a cartilha da obsolescência programada entram nas escolas e universidades e lá convivem com as tecnologias tradicionalmente pensadas e/ou usadas como educacionais. Por isso, não falamos aqui de substituição, mas de incrementos tecnológicos que alteram a nossa rotina, criando outros modos de habitar o mundo. A escola, ao contrário do que alguns possam pensar, faz parte deste mundo e não está imune às mudanças, é contaminada pelas práticas tecnológicas e o que se passa dentro dela conversa com o fluxo de experiências vividas no dentrofora das instituições de ensino.

Ao processo de circulação transmidiática de conteúdos, de uma tela a outra, rompendo as fronteiras do tempoespaço pela ubiquidade e pelos usos (CERTEAU, 1994) realizados por praticantespensantes(OLIVEIRA, 2012), Henry Jenkins (apud PRIMO, 2013) chama de cultura da convergência. Os conteúdos transitam em meios variados e são customizados de acordo com o usuário - a novela é vista em partes no celular ou de uma vez no tablete; o programa de auditório é reduzido a um único quadro que chama a atenção do espectador; a matéria do telejornal é replicada no Facebook a partir de um upload não autorizado e será acessada pela Smart TV, via wi-fi. Todo esse processo dar-se-á mediante a atuação do espectador, pois é ele quem escolhe os equipamentos e ressignifica as suas funções. As viabilidades técnicas, decerto, estão previstas no manual de instruções de cada máquina, mas as conexões e os usos serão da alçada dos praticantespensantes.

Tamanha autonomia e falta de cerimônia dispensada ao digital em rede nem sempre corresponde aos comportamentos adotados em sala de aula, diante dos recursos e materiais educativos apresentados pelos professores. As tecnologias educacionais são, muitas vezes, tratadas como obsoletas e desencadeiam no público certa apatia que torna a estadia numa sala de aula algo protocolar e maçante. Não obstante, ainda que o tédio possa parecer a paisagem própria dos prédios escolares, é preciso não esquecer que um dos pilares da educação a distância praticada no país é a insistência na transposição de gestos didáticos que já deixaram de fazer sentido no ensino presencial.

Usar na $E A D^{13}$ um referencial da sala de aula clássica é um equívoco. Trata-se de uma inconsequência pedagógica enxergar um $\mathrm{AVA}^{14}$ como repositório de PDF, traduzir a velha

\footnotetext{
${ }^{13}$ É preciso diferenciar EAD e educação online. A educação online é uma modalidade da EAD, pautada pelo uso de equipamentos conectados à Internet. Neste texto, referimo-nos às múltiplas formas de produzir a modalidade a distância, sendo a online uma das mais relevantes na atualidade. Mais especificamente estamos considerando práticas de EAD que mesclam interações online com distribuição de apostilas e encontros presenciais em pólos destinados a "tirar" dúvidas.

${ }^{14}$ Ambiente Virtual de Aprendizagem.
} 


\section{Revista Docência e Cibercultura}

lousa para slides em movimento, acreditar no fórum como incremento para conversas espontâneas quando, na verdade, faz dele um espaçotempo de interações reativas onde o cursista responde ao professor online porque entende que este movimento faz parte do processo avaliativo. A lógica da EAD dificilmente escapa do modelo escolástico e, quando tenta ser mais antenada, acaba conversando com a produção audiovisual mais engessada, pautada na comunicação pretensamente controlada e reduzida a dois pólos de emissão, lineares e previsíveis. Temos, pois, elementos plausíveis para apontarmos similaridades entre a educação a distância e parte das irrelevâncias didáticas da modalidade presencial. E isso nem sempre é da ordem do circunstancial, da coincidência, mas repousa em uma cultura transmissional e conteudista, cujo horizonte de eficiência seria produzir um estudante autônomo, controlador do seu tempo de estudo, uma vez que possui praticamente tudo o que precisa para realizar sua formação: conteúdos organizados, canais abertos de comunicação, um ambiente online amigável e toda estrutura hipertextual da Internet ao seu dispor. Mas entre a oferta do novo e o hábito cultivado e não desconstruído por quem propaga a novidade, existe um abismo no qual caímos todos, sem rede de segurança ou equipes de resgate prontas a nos auxiliar.

O que pretendemos indicar é que a EAD é uma aventura ainda insuficientemente mapeada e que, uma vez explorada, caberá aos seus atores desenhar caminhos próprios para trilhar objetivos e contemplar paisagens outras. Vestir a EAD com as roupas do ensino presencial ou achar que basta inserir a máquina para conduzi-la aos novos hábitos do mundo digital é um risco que não podemos correr. E, por precaução didática, é sempre bom não esquecer que o ensino a distância não se reduz ao computador - essa é apenas a sua versão online.

A EAD no Brasil, por exemplo, por muito tempo, teve na teleeducação o seu foco produtivo. Nos anos 1970, apostando no trajeto evolutivo da oferta educacional, diversas iniciativas elegeram a televisão como maquinaria adequada para levar a formação escolar a quem não podia ir à escola. O destaque dessa oferta ficou por conta da Fundação Roberto Marinho que, em parceria com a Fundação Padre Anchieta, criou o Telecurso 2ㅇ Grau, em 1978. O empreendimento, que unia TV e material impresso, pode ser citado como um incipiente gesto de convergência. Se através da televisão o aluno descortinava as 
possibilidades do audiovisual como linguagem para aprenderensinar, ele tinha no material impresso - mais familiar no quesito tecnologia educacional - a "segurança" de uma formação que inovava sem abrir mão do culturalmente estabelecido. Os resumos dos conceitos, presentes na tela da TV também estavam nos livros e, negociando o novo e o antigo, o Telecurso foi ganhando adeptos e garantindo o seu lugar na história da educação brasileira.

Aliás, a bandeira da educação televisionada foi demandada, conforme Garrocini (2010), pelo Congresso Nacional da ditadura civilmilitar. Dizia o Diário do Congresso Nacional, em 1977, que "por muito que se amplie, o sistema escolar (ensino primário, médio, profissional e superior) dificilmente conseguirá atender a todas as necessidades educacionais do povo" (BRASIL, 1977, p.7383). A solução para aumentar a oferta educativa seria apostar na utilização da tecnologia como via de acesso a uma formação fora dos tradicionais bancos escolares. Levar certo tipo de mensagem educacional a lugares em que a escola não chegava era de suma importância para o regime político que comandava o país. Práticas educacionais previamente gravadas, passíveis de serem modificadas pela censura da época, propagadoras de ideias que não ameaçavam os interesses postos na política nacional. O Telecurso 2ำ grau era o modelo ideal que precisava ser exaltado.

Produzido pela emissora de maior audiência no país, veiculado três vezes ao dia e reprisado nos fins de semana, $\mathrm{O}$ Telecurso contava com os atores da emissora para chamar a atenção do público. A Editora Globo produzia os fascículos - que eram o equivalente aos livros - e os vendia nas bancas de jornal. O Telecurso não era igual à escola, mas também não precisava ser tão diferente. Outra inciativa decorrente dessa aproximação entre educação televisiva e ensino presencial foi a criação dos Centros de Recepção Organizada (CRO), que funcionavam como pontos de encontros para alunos do Telecurso que tinham dúvidas ou queriam interagir com os demais (GARROCINI, 2011). Guardadas as devidas diferenças, os CRO equivaleriam aos polos de EAD atuais que, por imposições legais, funcionam como lócus para a realização de provas e, em alguns casos, cumprem também funções pedagógicas de orientação.

Garrocini (2011), ao associar o Telecurso 2 Grau aos anseios ideológicos do regime civilmilitar acredita queficou claro que o regime militar utilizou-se de um curso de educação a distância por meio de um veículo de massa, a televisão, a fim de dirigir e formar a opinião pública, e também para fins da construção de uma democracia tutelada, aceitável, treinando-os para uma 


\section{Revista Docência e Cibercultura}

democracia imposta pelo regime autoritário, visando a atingir o maior número de pessoas, especialmente nas camadas mais baixas da população. Assim, era possível centralizar, organizar e integrar a sociedade civil nos moldes do projeto militar, caracterizando suas ações e propostas numa estratégia de hegemonia após anos de predomínio das ferramentas de violência e coerção. (GARROCINI, 2011, p. 116).

Todavia, sabemos que o poder existe em disputa e sempre deve ser visto como uma relação de forças que ora pendem para um lado, ora para outro (FOUCAULT, 2010). Assim, apesar da ligação intrínseca entre a oferta educacional do Telecurso 2으 Grau e os objetivos da ditadura civilmilitar, é importante observar as possibilidades abertas para o acesso a uma cultura letrada que, mesmo atravessada por interesses político-ideológicos, poderia ser uma porta de entrada para investimentos educacionais futuros.

\section{DA TV ÀS AUDIOVISUALIDADES}

Essa breve incursão histórica, mais que narrar fatos e curiosidades, nos serviu para mostrar a diversidade de apropriações que podemos fazer da oferta educacional, esteja ela inscrita no modelo convencional de salas de aula constituídas por corpos que vão à escola, seja ela pensada na modalidade a distância. A importância de conhecer essas histórias, de pensar os caminhos próprios de cada trajetória está em nos fazer entender que toda oferta educativa dialoga com intenções não necessariamente pedagógicas e é sob esta ótica que falamos em redes educativas cotidianas, destacando a televisão como interlocutora potente da nossa formação não apenas hoje, no auge da cultura da convergência, mas há muito tempo e de forma muito pensada por quem decide a programação televisiva - não só os editoriais jornalísticos, mas também toda a grade do entretenimento.

Não é nosso objetivo atribuir à televisão comercial o papel de vilã no hall de tudo aquilo que nos educa. Ao contrário, chamamos a atenção para formas muito peculiares de produção de conteúdos que, por meio da distração, da emotividade, da recorrência a memórias que nos são significativas, vão nos conduzindo a uma sensação de acolhimento, tornando-nos receptivos às múltiplas mensagens produzidas e veiculadas na TV. Nesse sentido, o que indicamos é que temos algo a aprender com a produção audiovisual 
televisiva, cuja longevidade e audiência informam a competência na abordagem e fidelização do público.

Neste momento já não nos deixaremos enganar sobre a possibilidade de atuação acrítica da televisão sobre mentes e corpos. Vimos que ao espectador estará disponível o gesto da atualização, dos passeios inferenciais, das decisões frente a todo conteúdo veiculado. Somos praticantespensantes e, como tais, usamos (CERTEAU, 1994) a programação televisiva e a partir dela produzimos significações e subjetivações. Toda apropriação conversa com nossas bagagens prévias e com as nossas trajetórias.

Certamente, nossa capacidade de apropriação depende, em grande medida, das nossas sabedorias e ignorâncias nas múltiplas linguagens praticadas hoje em dia. $O$ manuseio dos conteúdos, a hibridização de formas e conceitos, a edição de sons e imagens, isto é, a prática das audiovisualidades tem a ver com a nossa localização entre os nativos ou entre os imigrantes digitais (PRENSKY, 2001). Há uma diferença geracional que não pode ser ignorada.

Do contato ativo e criador com a cultura da convergência as pessoas - em especial os jovens - desenvolvem habilidades e curiosidades tecnológicas. Constroem um repertório técnico variado que irá somar-se a tantos outros saberesfazeres já produzidos. Tais conhecimentos e noções adentram as escolas e não podemos ignorar seu potencial formador.

Precisamos, em nossa prática docente, considerar os hábitos de consumo audiovisuais dos estudantes, integrando ao programa das disciplinas que ministramos os saberesfazeres advindos desde consumo-criador. Seja no campo do debate, repercutindo alguma cena transmitida pela TV, seja nas apropriações das técnicas apreendidas no decorrer dos usos que fazemos com o audiovisual, precisamos tecer possibilidades, estimulando o fazer com os equipamentos e o desconstruir discursos veiculados, de modo a conceber a produção televisiva e suas derivações como matéria-prima de aprendizagens cotidianas e como tecnologias de acesso a uma linguagem de alto valor social - linguagem esta que precisamos dominar, ganhar fluência, inserindo nela o nosso sotaque, as nossas marcas.

Ao percorremos as teias dessas conversas transmidiáticas precisamos produzir discursos, imagens, leituras possíveis com os meios que dispomos. Através das nossas câmeras gravamos depoimentos, fotografamos pichações nas paredes do banheiro, 


\section{Revista Docência e Cibercultura}

juntamos a ela alguma trilha sonora e fabricamos uma espécie de filme caseiro que conta uma história ou propõe certo diálogo com imagens produzidas por outros - inclusive profissionais - e publicamos no ciberespaço este híbrido audiovisual cujas fronteiras inexistem e cujo alcance é impossível de prever. Chamamos essa produção com imagenssons-movimentos-ideias-prints-etc de audiovisualidades.

De acordo com Killp (2012), as audiovisualidades são o modo como vem sendo chamadas as produções engendradas no limiar do audiovisual, embaçando as fronteiras construídas pelos pesquisadores e realizadores entre códigos imagéticos, gêneros e produção-consumo. Operamos com esse conceito na formação de professores, estimulando a produção de recursos e materiais educativos que considerem as novas formas de compartilhamento e registro de imagens e ideias como espaçostempos de autoria, de invenção da própria aula, de expressão de um modo particular de viver e produzir a docência.

O que estamos apostando, em última instância, é na emergência de um profissional que seja não apenas um professor, mas um professor-designer-de-experiências, algo que na Educação a Distância é cunhado, equivocadamente, como designer instrucional. O termo instrução não nos parece o mais adequado, pois indica a prática do treinamento quando deveria estimular a curiosidade tecnológica, a abertura para a experimentação, a mescla de linguagens para a aquisição de uma fala plural, descomprometida com filiações definitivas, isto é, o professor-designer-de-experiências é um mediador entre o estudante e o mundo a ser conhecido/explorado e não um instrutor de saberesfazeres parados no tempo. Acreditamos ser imperativo apostarmos na valorização do professor-fazedor, um artífice (SENNET, 2012) que reelabora seus afazeres a partir daquilo que julga ser importante. Tratase de um profissional engajado, cônscio de que fazer é pensar, inquieto, investido de habilidades individuaiscoletivas, autor e coautor de artesanias didáticas, capaz de criar produtos que ultrapassam o previsível das técnicas.

Se a televisão, em grande medida, nos forma, por que não fazemos televisão? Fazer no sentido de produzir autorias a partir dela, mixar seus sons e imagens, bricolar seu conteúdo com tantas outras informações novas ou velhas, nossas ou de outros. Fazer ressoar o seu conteúdo, misturando-o aos conceitos de cada matéria, criticando o que nela 
reafirma desigualdades e preconceitos, lendo de outro jeito seus diálogos e suas imagens.

Sabemos que na cultura da convergência a televisão é uma face importante do consumo audiovisual, mas não é a única. Cada vez mais cedo as crianças são iniciadas nas tecnologias digitais e aprendemensinam aos pais a mixar conteúdos. A fluência na linguagem tecnológica não demanda na atualidade cursos específicos de iniciação. Encontra-se dispersa nas práticas, na cidade conectada, nas bicicletas alugadas pelo aplicativo de celular, nos caixas eletrônicos, na biometria da marcação de ponto no trabalho, no autoatendimento do cinema etc. Diante de tantos sistemas interligados que parecem nos lançar em um cenário de filme futurista não é de causar espanto a apatia percebida em alguns estudantes das nossas salas de aula. Estariam essas salas, online ou presenciais, adaptadas ao mundo touchscreen que nos rodeia e nos produz?

As mudanças que experimentamos diariamente nem sempre nos deixam tempo para processos de adequação. Quando vimos já tínhamos um controle de projetor em nossas mãos e no lugar do quadro negro agora tem uma tela que desce comandada por um botão na parede. O conteúdo da aula pula da página do livro para o software de apresentação que é formado por slides. Os slides são projetados na tela que está na frente do quadro negro que há algum tempo é uma lousa branca - e o professor vai passando esses slides com um apontador eletrônico, conectado ao computador por uma porta USB.

Ao descrevermos brevemente uma prática comum entre professores hoje em dia - a mobilização de recursos tecnológicos para a realização de uma aula expositiva - desejamos sublinhar a importância de pensarmos as tecnologias educacionais como processos de apropriação e invenção cotidiana de gambiarras didáticas. Ressaltamos a urgência de se olhar para o consumo de artefatos tecnoculturais - dentre eles a televisão multiplicada em telas - retirando deste consumo possibilidades de interação com os estudantes, reconhecendo o caráter formador de suas práticas teleciberculturais. Todavia, indagamos: o professor precisa ensinar os estudantes a ver TV ou devemos aprender com eles os modos de (se) ver e (se) produzir em múltiplas telas, negociando sentidos e praticando autorias?

As audiovisualidades, tanto no plano do consumo quanto no plano da produção, apresentam ao professor as possibilidades do faça você mesmo e/ou do manuseio sem reservas, indicando que saberesfazeres são produzidos em conversas entre corpos e máquinas. Corpos que são como antenas a captar sinais; máquinas que são produções humanas abertas à customização. Diferente do modelo de encenação do Telecurso 2 o grau, 
onde a ficção servia à instrução, a invenção proposta pelo conceito de audiovisualidades passa pela autoria coletiva e pela bricolagem imagética. A imagem aqui é pensada como via de acesso a um mundo que será, por cada um de nós, significado e não como processo de internalização de instruções previamente formuladas.

Por sua natureza híbrida, as audiovisualidades nos falam das possibilidades de fabricar com, de misturar conhecimentos e produzir um outro a partir de uns tantos. Por sua abertura ao compartilhamento as audiovisualidades inspiram a troca e produzem laços em redes sociais distintas. Por borrar as fronteiras entre os códigos estabelecidos, autorizando linhas de improviso, as audiovisualidades indicam que hierarquias podem ser dispensadas, dando lugar a diálogos mais livres.

Eis o desafio apresentado aos professores e estudantes: encontrar nas práticas contemporâneas de produção e consumo de imagens um caminho para a sistematização dos processos de aprendizagem. Não se trata de pedagogizar equipamentos e formatos, mas de apropriar-se deles, conferindo-lhes novos usos para além dos já praticados. É mais diálogo que conversão; é encontro e não disputa.

\section{REFERÊNCIAS}

ALVES, N. A formação da professora e o uso de multimeios como direito. In: FILÉ,Valter. Batuques, fragmentos e fluxos: zapeando pela linguagem audiovisual no cotidiano escolar. Rio de Janeiro: DP\&A, 2000, pp. 25-40.

- Nilda Alves: praticantepensante de cotidianos. Organização e introdução: GARCIA, Alexandra; OLIVEIRA, Inês Barbosa de. Belo Horizonte: Autêntica Editora, 2015.

BHABHA, H. O local da Cultura. Belo Horizonte: Ed. UFMG, 1998.

BOURDIEU, P. Sobre a televisão - seguido de A influência do jornalismo e Osjogos Olímpicos. Rio de Janeiro: Jorge Zahar Editor, 1987.

BRASIL. Decreto Legislativo no 110. Diário do Congresso Nacional da República Federativa do Brasil. Poder Legislativo, Brasília DF, 10 de dez. de 1977. Seção II, p. 7883-7585.

CERTEAU, M. A invenção do cotidiano: 1: artes de fazer. Petrópolis, RJ: Vozes, 1994.

ECO, U. Seis passeios pelos bosques da ficção. São Paulo: Companhia das Letras, 1994. Obra Aberta. São Paulo: Perspectiva, 2005. 
FOUCAULT, M. Em defesa da Sociedade: curso no Collège de France (1975-1976). São Paulo: Editora WMF Martins Fontes, 2010.

GARROCINI, E. Educação a Distância na Ditadura Militar no Brasil: O caso do Telecurso 2o Grau.Curitiba: UniversidadeTuiutido Paraná, 2010.

KILPP, Sa. Dispersão-convergência: apontamentos para a pesquisa de audiovisualidades. In: MONTAÑO, Sonia; FISCHER, Gustavo: KILPP, Suzana. Impacto das novas mídias no estatuto da imagem. Porto Alegre: Sulina, 2012. P. $223-238$.

OLIVEIRA, I. B. Currículos e pesquisas com os cotidianos: o caráter emancipatório dos currículos 'pensadospraticados' pelos 'praticantespensantes' dos cotidianos das escolas. In: Carlos Eduardo Ferraço e Janete Magalhães Carvalho (orgs.). Currículos, pesquisas, conhecimentos e produção de subjetividades. 1aed. Petrópolis: DP etAlli, 2012, p. 47-70.

MARCONDES FILHO, C. Televisão. Rio de Janeiro: Editora Scipione, 1994.

PRENSKY, M. Nativos digitais, imigrantes digitais. In: OntheHorizon. NCBUniversity Press, Vol. 9 No. 5, Outubro 2001.

PRIMO, A. (Org.). Interações em Rede. Porto Alegre: Sulina, 2013.

SENNET, R. O artífice.3. ed. Rio de Janeiro: Record, 2012. 